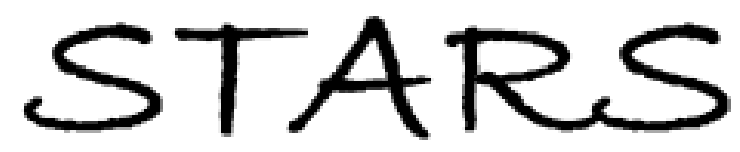

University of Central Florida

STARS

$1-1-2000$

\title{
"Happy days are here again": Cocoa farmers, middlemen traders and the Structural Adjustment Program in southwestern Nigeria, 1986-1990s
}

\author{
Ezekiel Ayodele Walker \\ University of Central Florida
}

Find similar works at: https://stars.library.ucf.edu/facultybib2000

University of Central Florida Libraries http://library.ucf.edu

This Article is brought to you for free and open access by the Faculty Bibliography at STARS. It has been accepted for inclusion in Faculty Bibliography 2000s by an authorized administrator of STARS. For more information, please contactSTARS@ucf.edu.

\section{Recommended Citation}

Walker, Ezekiel Ayodele, "'Happy days are here again": Cocoa farmers, middlemen traders and the Structural Adjustment Program in southwestern Nigeria, 1986-1990s" (2000). Faculty Bibliography 2000 s. 2849.

https://stars.library.ucf.edu/facultybib2000/2849

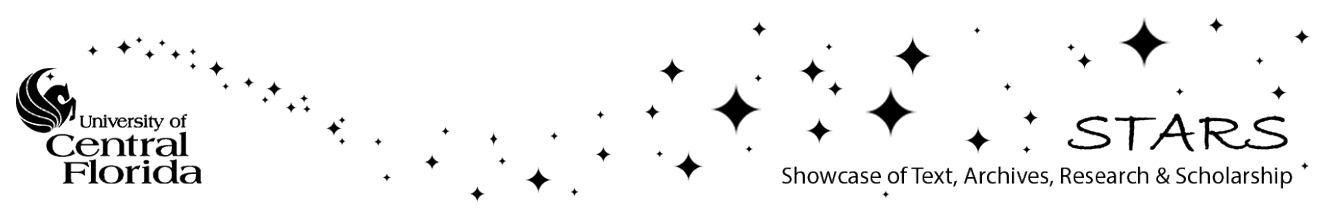




\section{凹 INDIANA UNIVERSITY PRESS}

"Happy Days Are Here Again": Cocoa Farmers, Middlemen Traders and the Structural Adjustment Program in Southwestern Nigeria, 1986-1990s

Author(s): Ezekiel Ayodele Walker

Source: Africa Today, Vol. 47, No. 2 (Spring, 2000), pp. 151-169

Published by: Indiana University Press

Stable URL: https://www.jstor.org/stable/4187335

Accessed: 30-07-2019 17:40 UTC

JSTOR is a not-for-profit service that helps scholars, researchers, and students discover, use, and build upon a wide range of content in a trusted digital archive. We use information technology and tools to increase productivity and facilitate new forms of scholarship. For more information about JSTOR, please contact support@jstor.org.

Your use of the JSTOR archive indicates your acceptance of the Terms \& Conditions of Use, available at https://about.jstor.org/terms

Indiana University Press is collaborating with JSTOR to digitize, preserve and extend access to Africa Today 


\title{
"Happy Days are Here Again": Cocoa Farmers, Middlemen Traders and the Structural Adjustment Program in Southwestern Nigeria, 1986-1990s Ezekiel Ayodele Walker
}

\begin{abstract}
This article examines the impact of the Structural Adjustment Program (SAP) that was installed by the military regime of Ibrahim Babangida in 1986 on the cocoa economy of southwestern Nigeria. The structural adjustment program resulted in the dissolution of the Cocoa Board. The scrapping of the Cocoa Board engendered significant changes in the marketing of cocoa, as Nigerian, and nonNigerian exporters (Syrians and Lebanese) sought to gain control of the cocoa trade. This resulted in a price war that led to a monumental increase in the price of cocoa. The cocoa boom from 1987 to 1988 was compounded by the heightened inflationary situation created by the structural adjustment program. Prices of farm implements rose and laborers also increased their wages. With the end of the cocoa boom in early 1989, some farmers found it increasingly difficult to maintain their farms, resulting in the intensification of sharecropping. Also, some laborers who had benefited from the windfall during 1987 and 1988 began to buy their own farms from cocoa farmers.
\end{abstract}

The structural adjustment program, which the Federal government of $\mathrm{Ni}$ geria inaugurated in 1986, was a response to the economic recession the country had been experiencing since 1982 . The recession was precipitated in part by the crumbling of the world oil market, and more fundamentally by structural weaknesses in the Nigerian economy which date back to the colonial period. Much has been written about the impact of the structural adjustment program on various aspects of the Nigerian economy. For example, Bola Akanji in two monographs published by the Nigerian Institute of Social and Economic Research (NISER) talks about the structural adjustment program and the proposed government ban on exporting raw 
cocoa beans. Akanji also discusses the emergence of new marketing arrangements in the cocoa industry but does not place the structural adjustment program in the context of the structural weaknesses of the Nigerian economy since the colonial period. As a result, the monographs lack a historical context, which is necessary to understand the impact of the structural adjustment program on aspects of the Nigerian economy, such as inflation and devaluation of the naira, and how they affect the cocoa economy of southwestern Nigeria. ${ }^{1}$ Furthermore, the monographs do not give a sense of change over time in relation to certain aspects of the cocoa industry, such as labor relations, land ownership, and the cost of maintaining cocoa farms.

Drawing on oral interviews done in Ife and Ondo, in southwestern Nigeria, this article addresses this lacuna by analyzing the impact of the structural adjustment program on the cocoa industry under three main headings. First, I examine the historical background to the inauguration of the structural adjustment program. Second, I discuss the broad outlines and objectives of the program. Finally, I assess the impact of the program on middlemen, cocoa farmers, labor relations, and the maintenance of cocoa farms. The analysis demonstrates, firstly, that the abolition of the commodity boards under the structural adjustment program resulted in significant changes in the organization of cocoa marketing. Cocoa marketing became more variegated as substantial numbers of individual exporters, both Nigerian and non-Nigerian, replaced the Nigerian Cocoa Board. Because of the need to control the cocoa market, there was a price war among cocoa exporters, which spawned an "artificial" boom in the cocoa economy from 1987 to early 1989 . The analysis shows, secondly, that the structural adjustment program generated a significant upturn in inflation. This increased inflationary situation resulted in a substantial increase in the prices of farm implements, which increased the cost of maintaining cocoa farms. Furthermore, laborers hiked their wages considerably and this, in turn, altered labor relations in the cocoa belt. Because of the prohibitive cost of labor, sharecropping intensified. Also, some laborers were able to parlay their financial success in the purchase of their own cocoa farms.

My fieldwork began at Akeredolu village, where I talked extensively with the chairman of the village, Chief Adedewe. He gave me a good sense of the layout of the cocoa belt of southeast Ife and provided me with names of cocoa farmers in other villages whom he felt would be informative regarding the history of cocoa production. Chief Adedewe then took me on a tour of his village and introduced me to each household. He felt that this act would dispel any apprehensions the farmers might have about my intentions. Farmers might have been reluctant to talk for fear that I was a government agent who had come to tamper with their land. I remained there for three months and got to know the farmers well. I rented a room in the house of Olodu, a hunter and foodcrop farmer, and made trips to other parts of the cocoa belt.

I selected informants from a cross section of the farming population. 
For the most part, I interviewed village elders who were direct descendants of the founding landowning families of the different cocoa villages. The village population in Ife and Ondo generally regards these elders as repositories of the history of cocoa farming because they have a firsthand account of its origin and growth. Besides, most of the migrant farmers I interviewed in southeastern Ife and Ondo also gave firsthand accounts of their experiences as they arrived together in these villages in the 1950s and 1960s.

I interviewed some farmers on an individual basis, because they were reluctant to talk in a group. They feared that their views might not be popular. Others did not feel comfortable with divulging intricate details about their cocoa farms to their peers. In cases where I conducted group interviews, I did so with the consent of the farmers. For example, the former landowners at Akeredolu were very willing to do group interviews. At Omifon Aladura, the elders of the village suggested that I conduct a group interview because, for the most part, they had good relations with one another and they each knew what the other possessed. I also did group interviews at Mofere, Molodo, and Legbira for similar reasons.

Laborers were generally more disposed to group interviews than farmers. This was because, in most cases, they worked in groups and tended to find strength in being together. Group interviews helped to minimize the problems of chronology and the dates of specific events. Although farmers were recounting events in the recent past, some of them could not remember the exact time of these events. The dynamics of group interviews allowed informants to cross-check the information they were providing with the accounts of other informants. I interviewed informants several times to confirm original recollections. In all of the cocoa villages I visited, I was able to make contacts with a cross section of the population. I discovered that developing an affective relationship with farmers and laborers made them more willing to talk about their experiences. Also, once they had me in their confidence, it was not difficult to ask them to comment on what others had said.

I interviewed fifty-five farmers and twenty laborers at Akeredolu, thirteen laborers at Legbira, and nine laborers at Mofere in the Idanre/Ifedore local government area. I also talked to farmers at Poso, Kere, Omifon Aladura, Isoya, Iyanfoworogi, and Osi-Soko. After touring several areas of the cocoa belt to get a good general knowledge of the changes created by the structural adjustment program, I prepared a questionnaire on specific aspects of cocoa marketing, labor relations, and farm maintenance. I collected information on the new marketing arrangements that evolved after the abolition of the commodity boards. I also obtained information on the number of laborers that cocoa farmers have used from the 1950s to the 1990s, and the cost of maintaining cocoa farms during the period of study. In addition, I obtained information from laborers regarding when they arrived at the villages, the wages they received from cocoa farmers over time, and when they established their own farms. The experiences of the vil- 
lages where I conducted interviews are representative of the changes that occurred in the cocoa farming areas as a result of the structural adjustment program.

\section{Historical Background}

The oil boom of the 1970s and early 1980s ushered in a period of unparalleled economic prosperity in Nigeria. This period was characterized by phenomenal increases in oil prices because of the embargo on oil exports to the West by Arab nations in the wake of the Yom Kippur War of 1973. Oil prices rose from a paltry $\$ 4$ a barrel in 1973 to about $\$ 42$ in 1980. Furthermore, oil revenues accruing to the Nigerian state rose from $\$ 7.761$ billion in 1975 to $\$ 15.7$ billion in 1979 , and $\$ 24.9$ billion in 1980 . This windfall from the oil embargo occurred at a time when the world economy was in recession. As most African countries were smarting from the effects of a global recession, the Nigerian economy was experiencing phenomenal growth. This economic prosperity was reflected in the growth of industrial capacity and gargantuan construction projects sponsored by the Federal government of Nigeria (Ahmad 1994: 183-4).

The oil boom came to an end in the early 1980s for various reasons. Western nations, initially caught unawares by the embargo imposed by the Organization of the Petroleum Exporting Countries (OPEC), began to pursue a policy of oil conservation. Also, the increasing output of non-OPEC producers like Mexico made it possible for Western economies to stockpile oil. Consequently, the share of OPEC countries on the world oil market was reduced. Nigeria, an OPEC member, felt the decline. Production of crude oil in Nigeria declined from about 2.056 million barrels a day in 1980 to 1.434 million in 1981, and to 1.229 million in 1982. The fall in the volume of production, coupled with significantly reduced oil prices, led to a progressive decline of Nigeria's oil earnings-from \$24.9 billion in 1980 to $\$ 12.5$ billion in 1985 , to about $\$ 5.6$ billion in 1986 (Ahmad 1994: 184).

The collapse of oil prices in the early 1980s brought into sharp relief the structural weaknesses of postcolonial Nigeria and generated an economic crisis of great magnitude. First, the decline of Nigeria's foreign exchange earnings engendered a balance of payments crisis, which was reflected in the country's external debt. It rose from 12.8 billion naira in 1981 to 21.2 billion naira in 1985. Although agricultural production increased by $3.4 \%$ between 1980 and 1981, industrial production declined by $7.9 \%$. Nigeria's external reserves diminished by over $50 \%$ in 1982 (Yahaya 1993: 17).

The recession of the post-oil boom period was precipitated, in large measure, by contradictions in the economic policies formulated by the Federal government of Nigeria in the immediate postcolonial period. In the early 1960s, Nigeria adopted a mixed economy with a lopsided emphasis on industrial development. Industrial development was pursued on the 
basis of import substitution, which was intended to diversify the Nigerian economy and facilitate transfer of technology (Colman and Okorie 1998: 341-55). Financing for the various industrial projects would come from revenue generated from agriculture. In pursuing its policy of import substitution, the Nigerian government failed to modernize and develop the agricultural sector. The agricultural sector still had vestiges of the colonial period. The marketing boards that had been set up in the colonial period to stabilize cash crop prices were continued in the postcolonial period, and became veritable conduits for appropriating surplus. Furthermore, Nigerian agriculture was based on only a few cash crops.

The oil boom of the 1970s and early 1980s disguised the rather tenuous economic foundation of Nigeria's postcolonial state. The oil boom allowed Nigeria to intensify its efforts at import substitution. But import substitution itself was flawed. Firstly, it had very few supporting links within Nigeria. Secondly, it did not generate any significant multiplier effects on the Nigerian economy. Instead of utilizing local raw materials, import substitution industries were externally driven. Consequently, the postcolonial Nigerian State had to spend the majority of its foreign exchange on spare parts for these industries (Olukoshi 1993: 2-5).

This arrangement was fine as long as there was enough foreign exchange from oil to maintain these industries. With the onset of the economic recession of the mid-1980s, however, Nigeria not only had to cut back on government spending, but also had to dip into its foreign reserves. In order to stop the free fall of the Nigerian economy, the Shagari government inaugurated the Economic Stabilization Program of 1982. The program was designed to limit import licenses, raise duties, and reduce public expenditure. Also, the government hiked tariffs and the price of fuel. These measures, however, proved ineffective as oil prices declined dramatically by $45 \%$ from the 1980 prices. The economy only worsened. GDP dropped by $4.4 \%$, and industrial production declined by a phenomenal $11.8 \%$. Furthermore, the rate of inflation, which was $10 \%$ in 1980 , had risen to $23.2 \%$ in the closing days of the Shagari regime. Although the efforts to reduce imports yielded dividends, as imports dropped by $23 \%$, the trade deficit remained at about 2.1 billion naira, and external reserves declined precipitously from approximately $\$ 8.5$ billion in May 1981 to approximately $\$ 2.5$ billion at the end of the year. Fiscal indiscipline and mismanagement, which characterized the Shagari regime, compounded the economic situation (Yahaya 1993: 16-17; Fadahunsi 1993: 36).

Because of the growing crisis in the Nigerian economy, the Shagari government approached the International Monetary Fund (IMF) for a loan of between 1.9 and 2.4 billion naira. The IMF, however, demanded the installation of a number of policies before the loan could be granted. These conditions included a drastic reduction of government spending, privatization of public sector establishments, liberalization of trade-through a relaxation of tariffs-and a removal of subsidies and government controls on imports. No definite arrangements were made with the IMF before the 
Shagari regime was ousted in a military coup in December 1983 (Ahmad 1994: 189).

The new military government of Buhari and Idiagbon intensified the austerity measures initiated by the Shagari government. It attempted to reduce government spending by retrenching government employees and imposing fees on health care and education. Furthermore, the regime initiated a vigorous debt repayment plan, with the IMF and other foreign creditors, which depleted Nigeria's foreign reserves and escalated the economic crisis. The regime also made drastic cuts in allocations for spare parts and infrastructure. Consequently, there were substantial declines in several vital areas of the economy. For example, industrial production fell and several plants closed because it became difficult to purchase imported raw materials. The rate of inflation rose from $23.2 \%$ in 1980 to $40 \%$ in 1984 . By 1985 , the contradictions in the economy had deepened considerably.

In spite of the spirited attempts of the military regime of Buhari and Idiagbon to revamp the Nigerian economy by imposing fiscal discipline and curtailing government spending, the continued fall of oil prices led to a further accumulation of debts and a deterioration of the Nigerian economy. It is generally accepted that the military regime of Buhari and Idiagbon tried to grapple with the incredible downturn in the Nigeria economy, but there were forces within the military that felt the time was ripe for a new direction. The military struck, yet again, on 26 August 1985, in a bloodless putsch under the aegis of Ibrahim Babangida. After reorganizing the supreme military body, the new military leaders declared that a drastic restructuring of the economy was necessary to stem the seemingly irrepressible tide of economic disintegration. In response to another significant drop in oil prices, the Babangida regime, in October 1985, declared a fifteen-month period of national economic emergency. At the same time, multilateral financial institutions, such as the World Bank and the IMF, made it clear that for Nigeria to receive additional loans it had to implement certain conditionalities under the framework of Structural Adjustment (Ihonvbere 1994).

The Babangida administration threw up the issue of Structural Adjustment and the IMF's $\$ 2.5$ billion loan program for public debate. After about a year of open debates and discussions, it was clear that public opinion was against the structural adjustment program. The private sector was concerned that trade liberalization would undermine domestic industries and that they might not be able to compete with imports. Others were worried that the IMF loan would be mismanaged. Yet others were opposed to the proposed devaluation of the naira by an external financial agency.

Although the Babangida administration acceded to the wishes of the Nigerian people by rejecting the IMF loan, the government did accommodate some of the conditions of the IMF by agreeing to a structural adjustment program. This was evidenced by the reform budget of 1986 that slashed the subsidy on petroleum products by $80 \%$. Trade liberalization and privatization also were accepted in principle. The World Bank and the 
IMF, however, dismissed these reforms and demanded an adjustment of the exchange rate. Consequently, in August 1986, the Babangida administration initiated its structural adjustment program, which incorporated a two-tiered foreign exchange system to devalue the naira. Although the government did not accept the IMF loan, the World Bank and the London and Paris Clubs agreed to new loans and debt rescheduling (Olukoshi 1993).

\section{The Structural Adjustment Program and the Restructuring of Cocoa Marketing}

The structural adjustment program was designed to diversify and reconfigure the Nigerian economy by stimulating domestic production in the agricultural, manufacturing, and industrial sectors. Furthermore, it was hoped that by generating internal production through the utilization of local raw materials, the balance of payments deficit would be reduced and a diminution of Nigeria's dependence on Western imports would follow. The structural adjustment program also strove to deregulate the economy by removing administrative encumbrances and reducing the stranglehold of government on the economy. It also sought to devalue the naira and rationalize tariffs. This new economic philosophy, according to the government, was intended to effect liberalization of trade, privatization, and the fostering of a market economy (Olukoshi 1993).

The agricultural sector of the Nigerian economy was central to the government's plans to achieve the objectives of the structural adjustment program. The agricultural resources of the country would be harnessed to provide raw materials for industrial production. It was also hoped that the removal of government controls from agricultural marketing would increase the prices of export crops such as cocoa, palm oil, rubber, and cotton, and provide much needed incentive to farmers to increase production.

In the early stages of the structural adjustment program, certain important reforms were implemented. The naira was devalued, the import licensing system was abolished, and major structural changes were effected in the marketing of agricultural exports. These changes included: the withdrawal of government from the distribution of inputs and agricultural produce, the eradication of government subsidies on agricultural inputs, and the scrapping of the commodity marketing boards. The scrapping of the commodity boards is arguably one of the most revolutionary changes that has taken place in the postcolonial period. By 1983, the marketing boards had come under increasing obloquy by academics, and political and economic commentators, who directly related the decline in commodity production to the exploitative tendencies of the boards. The news of the elimination of the marketing boards was received gleefully by farmers, who attributed their impecunious situation to the activities of the boards.

There was considerable optimism that the cocoa markets, which had been paralyzed for a long time, would become buoyant under the new con- 
figuration. This optimism in the emergent framework was based on the assumption that, since the farmers would now have a greater stake in the sale of their cocoa, they would invariably have the leverage to determine cocoa prices. Cocoa prices would now be based purely on market forces, and farmers looked forward to having the upper hand in the negotiations that would result from the new marketing arrangement (Group Interview $1989 a, 1989 b, 1989 c) .^{2}$

Pursuant to the dismantling of the commodity marketing board, the government announced new requirements for participating in the agricultural export trade. According to Decree No. 18 of $1986,{ }^{3}$ the government would issue licenses to two categories of exporters. In the first group were private exporters, comprised of foreign merchants and indigenous buyers. These exporters are allowed to trade in particular export crops between Nigeria and the world market. In the second group were union exporters, which were made up of cooperative organizations created by farmers to market their cocoa. This group, for the most part, sold cocoa to agents of the Association of Nigerian Cocoa Exporters (ANCE). These exporters had huge capital expenses as they constructed warehouses in the cocoa-growing areas and in the main port in Lagos, to store their cocoa. In addition, they each had to pay registration fees of about 10,700 naira (Akanji 1992).

Prior to the introduction of the structural adjustment program, the majority of all cocoa produced was sold through cooperative marketing unions, licensed buying agents, or itinerant buyers, to the Nigerian Cocoa Board. According to Bola Akanji, this structure did not change with the onset of the structural adjustment program, but became more diversified. For example, more women are now involved in buying cocoa than ever before. Akanji states that about $50 \%$ of itinerant cocoa buyers were women and about $25 \%$ of them had just entered the trade. They used bags, bowls, knives, and scales and bought small quantities of cocoa which fluctuate from a few kilograms to about half a bag of cocoa (Akanji 1992).

It can be argued, however, that the dissolution of the commodity boards had profound consequences for the organization of cocoa marketing, as individual exporters now supplanted the Nigerian Cocoa Board. Furthermore, in spite of the massive operating costs and the high registration fees, the deregulation of the cocoa industry led to a proliferation of individual produce buyers and export merchants. As each of these groups of cocoa buyers sought a controlling influence on the cocoa market, a vicious price war ensued. Consequently, the price of a ton of main crop cocoa, which sold at between 1,600 naira and 2,000 naira toward the end of 1986, rose to 7,500 naira at the end of the 1987-1988 marketing season.

This upward trend continued with the cocoa light crop, which was harvested from May through and August. ${ }^{4}$ In the early part of 1988, the price of cocoa rose phenomenally from about 7,500 naira per ton to as much as 11,000 naira per ton. It was selling at 16,000 naira per ton by the end of 1988. Farmers' growing knowledge of the dynamic of the foreign exchange market led them to ask for higher prices. The phenomenal in- 
creases in cocoa prices happened at a time when cocoa prices were falling on the world market, from approximately $\$ 2,134$ in December 1987, to below $\$ 1,800$ by the end of 1988 (Akanji 1992).

Some farmers succeeded in parlaying the price war into a huge financial success. For example, nine of fifteen farmers whom I interviewed at Igbo-Oja village in Ondo had made a profit of over 40,000 naira during the cocoa boom. Two out of the nine scaled the 100,000 naira profit mark (Group Interview 1989a). At Akeredolu village in southeastern Ife, I interviewed 30 farmers regarding their incomes during the boom. Of those interviewed at Akeredolu, ten had realized over 40,000 naira (Group Interview 1989c). At Omifon Aladura, on the Ondo-Ore road, three of ten informants made a profit of upwards of 80,000 naira each (Group Interview 1989b). At Fagbo village "via" Ondo, síx of twelve informants had made over 50,000 naira (Group Interview 1989d). ${ }^{5}$ There is no question that all over the cocoa belt there were farmers who benefited enormously from the cocoa boom. This fact is corroborated by newspaper reports, which attest to the increased standard of living of rural farmers. Cocoa farmers now flaunted their newfound wealth by buying expensive cars, such as Peugeots, Mercedes Benzes, and similar vehicles. Some of them organized parties and became frequent visitors to beer parlors where they sometimes drowned themselves in bacchanalian revelries. Indeed, for the farmers of the cocoa belt and some other traders associated with the cocoa industry, these were happy times (Group Interview 1989a, 1989b, 1989c). ${ }^{6}$

For indigenous produce merchants, however, it was a difficult period. Only a few indigenous merchants, such as Lawrence Omole and Chief Fagboyegun, had the capital to compete effectively with the expatriate merchants. In an article entitled "Aliens hijack Cocoa Trade," published in the Sunday Sketch, 18 December 1988, Goke Olatoye reported that export firms owned by non-Nigerians, notably Kopek, Wasseli, and Afro-Continental Exporters, had taken over the produce trade and rendered many indigenous merchants dormant. For the most part, export firms owned by non-Nigerians were large-scale enterprises with extensive international banking connections. The Lebanese and Syrian traders who own these companies had greater access to bank loans than Nigerian exporters because they could provide the necessary security. Some of these companies have been in Nigeria since the colonial period and have achieved considerable success in a wide range of businesses, such as transportation, import and export trade, retailing, and the service industry (Sunday Sketch 1988).

In contrast, Nigerian merchants in the ANCE, an indigenous export firm which had handled between 20,000 and 30,000 tons annually since 1960 , were able to market only about 4,043 metric tons of cocoa in the 1988-1989 season. Some indigenous produce merchants, however, who had been courageous enough to buy cocoa at this time, in the hope that the price would pick up on the world market, incurred monumental losses. Chief Fagboyegun, arguably the foremost indigenous produce buyer in $\mathrm{Ni}$ geria, lost approximately 10 million naira to speculation. According to his 
son, who was one of the directors of the company, they had stockpiled about 1,500 tons of cocoa, which they had bought at about 24,000 naira per ton. With the price crash of mid-1989, the company had to hurriedly sell their cocoa at drastically reduced prices. There are many cases of indigenous buyers who lost in the price bust following the cocoa boom era (ANCE Annual Reports 1988, 1989). ${ }^{7}$ In explaining the plight of indigenous exporters, Kayode Ola, Managing Director of Lagricom, a big export company, argues in his article entitled, "A Case for Indigenous Merchants," published in Sunday Sketch, 24 September 1989, that the Federal government gave the non-Nigerian export merchants the scope to exploit the cocoa trade without regulation. He opines that the foreign-owned export firms, due to their international banking ties, could secure foreign exchange much easier than their Nigerian counterparts. They could also get bank loans in the Nigerian currency. As a result of this advantage, expartriate merchants completely dominated the export trade. Ola also contends that the large disposable amounts of the Nigerian currency held by foreign merchants artificially created the cocoa boom. The downward slide of the naira allowed them to buy increasing amounts of cocoa in the knowledge that they could sell it on the world market for hard currency. Nigerian farmers, on the other hand, maximized their earnings by taking advantage of the competition among the foreign export merchants for the cocoa market (Sunday Sketch 1989).

This bizarre economic behavior should be situated within the context of the structural adjustment program. As stated earlier, the Babangida regime, in order to facilitate the devaluation of the naira, created in September 1986, a second-tiered foreign exchange market (SFEM), later known as Inter-Bank Foreign Exchange Market, and then changed to Foreign Exchange Market. The SFEM presided over the auction of a specific amount of hard currency, notably US dollars, which it was allocated every week by the Central Bank. Commercial banks and specialized foreign exchange dealers were allowed to bid for up to $5 \%$ of the foreign currency allocated for the day. The lowest bid in the auction was used to set the exchange rate of the naira in relation to the US dollar. The devaluation of the naira continued even after the merger of the first- and second-tier markets (Fadahunsi 1993).

Fadahunsi shows that the creation of the second-tiered foreign exchange market had led to the devaluation of the naira against the hard currencies of the cocoa-buying nations of the world. As figures in Table 1 show, the exchange rate of the naira to the US dollar fell, from 1 naira to the dollar in 1985, to 4.52 naira to the dollar in 1988. Furthermore, there was a dearth of foreign exchange on the Nigerian money market. He argues that foreign-owned cocoa export firms had lost confidence in the Nigerian currency and were willing to buy as much cocoa as possible, sometimes at ridiculously high prices, in the hope of getting hard currency on the world market. Armed with large amounts of naira, they were able to dominate 
TABLE 1: Annual Average Exchange Rate and Domestic and World Price of Cocoa ${ }^{8}$

\begin{tabular}{ccccccc} 
Year & $\begin{array}{c}\text { Average } \\
\text { Exchange } \\
\text { Rate } \\
\text { US\$ : naira }\end{array}$ & $\begin{array}{c}\text { Domestic } \\
\text { producer price } \\
\text { of cocoa per } \\
\text { metric ton } \\
\text { f.o.b. }\end{array}$ & $\begin{array}{c}\text { World market } \\
\text { price of cocoa } \\
\text { per metric ton }\end{array}$ & $\begin{array}{c}\text { Marketing } \\
\text { margin }\end{array}$ & $\begin{array}{c}\text { Producer } \\
\text { share }\end{array}$ & $\begin{array}{c}\text { Market } \\
\text { share }\end{array}$ \\
\hline 1980 & 0.54 & 1,300 & $1,456.2$ & 156.2 & 89.28 & 10.72 \\
1981 & 0.64 & 1,300 & $1,288.7$ & -11.3 & 100.9 & -0.9 \\
1982 & 0.67 & 1,300 & $1,201.0$ & -99.0 & 108.2 & -8.2 \\
1983 & 0.75 & 1,400 & $1,645.4$ & 245.4 & 85.1 & 14.9 \\
1984 & 0.81 & 1,500 & $2,015.4$ & 515.4 & 74.5 & 15.5 \\
1985 & 1.00 & 1,600 & $2,308.3$ & 698.3 & 69.5 & 30.5 \\
1986 & 2.22 & 3,500 & $3,633.2$ & 133.2 & 96.5 & 3.5 \\
1987 & 4.03 & 7,500 & $7,500.0$ & 00.00 & 100.0 & 0.0 \\
1988 & 4.52 & 11,000 & $8,000.0$ & $-3,000$ & 137.5 & -37.5
\end{tabular}

the cocoa trade in the first years of the structural adjustment program period by bidding up the domestic price of cocoa (Fadahunsi 1993).

The cocoa boom of the 1987-1988 season generated considerable debate on the pages of Nigerian newspapers. Furthermore, scholars have conflicting opinions regarding the impact of the structural adjustment program. For example, Rashid Faruqee, in a World Bank study, pointed to the phenomenally high prices of cocoa and its resultant benefits to farmers as one of the outstanding gains of the much vaunted program (Faruqee 1994). The apologists for the structural adjustment program have made these assertions without much attention to the fact that the boom was artificially created. Further, as my fieldwork suggests, only a small percentage of the farming population benefited. No attempt has been made to analyze whether or not there were any multiplier effects from the cocoa boom. ${ }^{9}$

There is no question that farmers with large holdings and substantial yields capitalized on the windfall to make huge gains. The extent to which their profits generated further growth within the economy needs to be evaluated. It should be pointed out that the vast majority of cocoa farmers who benefited from the boom spent a substantial amount of their profits rehabilitating their farms. Many of my informants claimed that, for the first time, they had the means to spray their cocoa trees and buy fertilizers. As a result, the volume of production rose significantly in southwestern Nigeria, from about 140,000 metric tons in 1987 , to about 253,000 metric tons in 1988 (Akanji 1992).

The cocoa boom was short-lived. By mid-1989, the world market price of cocoa dropped sharply as a result of a glut on the world market. This new development led to a drastic collapse in the domestic price of 
cocoa. Cocoa, which sold at between 17,000 and 22,000 naira per ton in March 1989, had plummeted to about 5,000 naira per ton in June, a decrease of about $64 \%$. The cocoa farmers, not particularly knowledgeable about the intricacies of the international financial system, nor the circumstances that led to the boom between 1988 and 1989, unleashed their venom on the indigenous exporters and the licensed buying agents (LBAs). The spokespersons for the farmers whom I interviewed betrayed their ignorance of the workings of the system by directly accusing these groups for the downturn in the fortunes of the cocoa industry. They stated that the indigenous exporters, together with the LBAs, had discouraged the foreign companies from continuing with the buying of cocoa at extravagant prices (Group Interview 1990a, 1990b, 1990c, 1990d; Akanji 1992).

Farmers refused to sell to indigenous buyers and began to negotiate directly with foreign companies. In cocoa villages, such as Aroko, Iyanfoworogi, Isoya, Osi-Soko, Akeredolu, and Kere, representatives met to discuss the possibility of forming groups and applying for licenses as buying agents. The farmers reasoned that, if they could get licenses, then their interest could be better served and they would have the leverage to curb the supposed interference of the indigenous buying houses. The farmers soon found themselves in a quandary. Non-Nigerian export firms, which were no longer willing to buy cocoa at a loss, refused to revert to the high prices of the boom period. Farmers could either sell their cocoa at drastically reduced prices or allow them to rot in their stores. The cocoa farmers held out for a while and demonstrated remarkable resilience in sticking to their demands. The withholding of cocoa by the farmers led to a reduction of cocoa exports by $450 \%$, from 29,331 metric tons in January 1989 , to 6,437 metric tons in August of the same year. A significant number of cocoa farmers suffered devastating losses. According to an editorial in the Sunday Tribune, 26 November 1989, a farmer at Bolorunduro village near Ondo described the 1989-1990 season as a "suicidal one." Samuel Akindunni stated that at the same time in the previous year, he had made about 80,000 naira. He withheld his cocoa in 1989 because his projected earnings could not exceed 15,000 naira (Sunday Tribune 1989).

\section{Impact of the Structural Adjustment Program on the Cost of Farm Maintenance}

The reaction of the farmers to the downturn in the price of cocoa should be put in perspective. The artificial boom between 1987 and 1989 occurred at a time when the Nigerian economy was experiencing a severe inflationary spiral. The rate of inflation, which was $5.4 \%$ in 1986 , rose to $38.3 \%$ in 1988 , and $40.9 \%$ in 1989 . Consequently, prices of farm implements rose substantially. Alhaji Arowolo Giwa, of Ilare village, complained bitterly that he never imagined that a time would come when he would buy a cutlass for 60 naira and a hoe for 50 naira. In Idanre, a leading cocoa-producing 
area in Nigeria, the cost of living rose significantly. Transport fares from Idanre to Akure, which formerly cost between 1 naira and 1 naira 50 kobo, rose to 5 naira. Food items such as beans, cassava flour, and rice sold at more than double their pre-SAP prices (Ekpo 1992).

The harsh economic realities of the collapse of cocoa prices in Nigeria led to an intensification of smuggling of cocoa beans across the border to neighboring West African countries, such as Benin and Togo. Smuggling of cocoa beans across the Nigeria-Benin border had been on the rise since 1984, when the economic recession in Nigeria became acute. The major cause of smuggling of cocoa beans was the steady decline of the naira against the hard currencies of the world market. Since smugglers of cocoa beans to Benin and Togo were paid in convertible currency, they were able to make decent profits on the parallel market. For example, one ton of cocoa, which sold for 1,500 naira in the 1983-1984 season, could fetch anywhere from 8,000 to 10,000 naira across the border. ${ }^{10}$ The border patrols have been unable to curb the trafficking of cocoa to neighboring countries. A 1989 Sunday Concord investigative report states that cocoa smuggling redoubled with the price collapse of mid-1989 (Sunday Concord 1989).

Of far more significance for the relations of production in the cocoa belt was the incredible rise in labor costs, chemicals, and fertilizers. The cocoa boom led to an intensification of a process that had begun with the oil boom when laborers began to exert their will upon cocoa farmers by demanding higher wages. One informant at Igbo-Oja village in Ondo said that, although he made a lot of money during the cocoa boom, he has had to spend extensively on labor. He said he has spent about 2,400 naira per annum since 1988 and 1989, as compared with the 250 naira he spent in the mid-1970s. The situation in southeastern Ife was not different from what obtained in Ondo. For example, at Akeredolu village, Yaya Adereti, a seventy-year-old farmer, said he had been spending about 2,000 naira on laborers since 1988, as compared with the 400 naira he used to spend in the 1970s (Adereti 1990). At Molodo village, Raimi Olayade told me during a group interview that since 1988 he had spent about 25 naira for fifteen heaps of cocoa (Group Interview 1990a). ${ }^{11}$

The phenomenal hike in the wages of laborers became a problem because laborers were demanding money for jobs, which they had contracted just before the slump occurred. Farmers were, therefore, faced with the difficult situation of paying the equivalent boom wages in an increasingly depressed cocoa economy. This of course generated a lot of tension in the cocoa villages as laborers geared for war against the farmers.

To compound this problem, the prices of fertilizers and chemicals increased with the abolition of the Cocoa Board. The Cocoa Board, through the Cocoa Subsidy Scheme, had made provisions for the supply of fertilizers and chemicals to farmers at subsidized rates. Although the evidence shows that most farmers did not get chemicals and fertilizers at the controlled rates, they were able to buy them during the cocoa boom. Although the cocoa boom ended in mid-1989, the prices of farm implements, fertiliz- 
TABLE 2: Average Prices of Major Farm Inputs in Nigeria (N/ton) 1984-198912

\begin{tabular}{|c|c|c|c|c|c|c|}
\hline Type of Input & 1984 & 1985 & 1986 & 1987 & 1988 & 1989 \\
\hline Hoe & 2 & 3.7 & 4.0 & 5.7 & 9.0 & 12 \\
\hline Matchet & 6 & 8.0 & 12.0 & 25.0 & 40.0 & 60 \\
\hline Sprayer & 150 & 185 & 260.0 & 400.0 & 450.0 & 480 \\
\hline Fertilizer $25 \mathrm{~kg}$ & 10 & 13.5 & 13.5 & 28.0 & 40.0 & 50 \\
\hline Agrochemicals $25 \mathrm{~kg}$ & 50 & 50 & 50 & 55.0 & 70.0 & 100 \\
\hline
\end{tabular}

ers, and chemicals did not drop. As figures in Table 2 show, the price of a 25 kilogram unit of fertilizer rose from 10 naira in 1984 to 28 naira in 1987, and then to 40 naira in 1988. The price of a 25 kilogram unit of agrochemical rose from 50 naira in 1984 to 70 naira in 1988, and then to 100 naira in 1989. Cocoa farmers thus found themselves in a double squeeze: one, from rising cost of labor, the other from the high prices of chemicals and fertilizers (Akanji 1992).

Related to these developments was the progressive decimation of cocoa trees by diseases. This phenomena led to a drastic reduction in output, as farmers watched helplessly as their cocoa trees have atrophied over time. The rapid spread of cocoa diseases needs to be put in context. According to Akanji, the amount of fertilizer used by cocoa farmers in the postboom period declined by $13.7 \%$, and the amount of Nuvagon used declined by $25 \%$. At Igbo-Oja village in Ondo, Mr. Jerome Akinsimidele told me in a group interview that in the 1950s and the early 1960s, when he became involved in cocoa production, the incidence of cocoa diseases was not prevalent. He said that he started spraying his cocoa trees from the late 1960 s, and, at that time, he used to spend about 110 pounds per annum to spray his cocoa trees. Beginning in 1980, however, my informant said there was a marked increase in the cost of farm maintenance. This trend reached its apogee in 1988, when he spent about 2,400 naira on chemicals and fertilizers alone. These examples are by no means isolated. They are a reflection of what appears to be a general trend. One of the most pronounced effects of the escalating cost of farm management has been the inability of cocoa farmers to cope with the ravages of cocoa diseases. This has led to the death of substantial numbers of cocoa trees and a decline in the output of cocoa farms (Group Interview 1990b). ${ }^{13}$

For instance, thirty of fifty farmers interviewed at Akeredolu had suffered substantial decreases in cocoa yields. Mr. Yaya Adereti, an informant at Akeredolu who used to realize about 3 tons of cocoa from his 30 -acre 
farm in the late 1960s, could get only about 1.5 tons by the mid-1980s. At Molodo, Sule Adefisoye told me that the initial output from his two farms used to be 2.5 tons before decline set in. The decline was not drastic initially, as he was able to get about 2 tons for some years. Beginning in 1984, however, Adefisoye began to realize just a little over a ton from his two farms. He went further to say that about one-quarter of his cocoa trees have been affected by diseases (Group Interview 1990a). The experiences of Mr. Olufowomade of Igbo-Oja in Ondo provide a broader perspective on the declining productivity of the cocoa-producing areas. Olufowomade inherited an 8-acre cocoa farm from his father in the 1950s and five years later bought 2 acres of virgin land in Oboto. In the late 1950s and early 1960s, he used to realize about eight bags of cocoa from his inherited farm. When his new farm at Oboto became productive by the turn of the decade, his combined yield rose to 2 tons. There has, however, been a steady decline in the output of his two farms since 1984. Olufowomade attributes this decline to the old age of the cocoa trees and the declining fertility of the soil, which have made the cocoa trees less fecund than they used to be. Furthermore, the old age of the trees has made them more vulnerable to diseases. This has been exacerbated by the inability of the farmer to keep up with the rising cost of chemicals and fertilizers. The informant also said that, although successive governments in Nigeria had made attempts to rehabilitate cocoa farms since the mid-1970s, these attempts have been halfhearted. Olufowomade went further to say that corrupt officials who diverted money that was meant for the project to personal use had undermined these programs (Olufowomade 1989). ${ }^{14}$

The inability of the farmers to spray their cocoa farms has resulted in decreasing yields and diminishing incomes. One of the most dramatic consequences of the structural adjustment program has been the emergence of a class of farmers who used to be laborers. These laborers were able to parlay the extraordinary increase in the cost of labor to great advantage, by buying cocoa farms from farmers who could no longer maintain them. Those who are unable to buy cocoa farms now rent farms from cocoa farmers for an agreed period of time. At Akeredolu village, where I interviewed all the laborers involved in the cocoa trade, the changes in the relations of production are brought into sharper relief. Of the twenty laborers in the village, nine of them now have their own cocoa farms. Eight of them, including one woman, still offered their services as daily-paid laborers and sharecroppers. Two of them are annual workers, and the remaining one is a renter (Group Interview 1990f).

The case of a thirty-two-year-old laborer-turned-farmer who hails from Ogoja in Akwa-Ibom State is instructive. This informant arrived at Akeredolu in 1987 and was employed as a laborer in the 1987-1988 cocoa season. As a result of the cocoa boom, he was able to buy his own piece of land on which he plants foodcrops such as cassava, cocoyams, vegetables, okra, and pepper. In addition, he rented a cocoa farm for three years at 1,400 naira in early 1989. I also interviewed all the laborers at Mofere vil- 
TABLE 3: Migrant laborers who own cocoa farms in selected villages in the cocoa belt ${ }^{15}$

\begin{tabular}{|c|c|c|}
\hline Village & $\begin{array}{c}\text { Number of Laborers } \\
\text { interviewed }\end{array}$ & $\begin{array}{c}\text { Number of migrant laborers } \\
\text { who own cocoa farms }\end{array}$ \\
\hline
\end{tabular}

$\begin{array}{lrl}\text { Akeredolu } & 20 & 9 \\ \text { Mofere } & 9 & 3 \\ \text { Legbira } & 13 & 5\end{array}$

lage in the Idanre/Ifedore local government area. Figures in Table 3 show that of the nine laborers in the village, four now have their own cocoa farms. The remaining still work on a daily-paid basis (Group Interview 1991a). At Legbira, five of thirteen laborers interviewed have their own cocoa farms (Group Interview 1991b)..$^{16}$

Positive changes in the local economy can be attributed to the structural adjustment program. Some laborers were able to purchase farms of their own. Cocoa also played a less prominent role in the lives of farmers than in earlier times. Most cocoa farmers have diversified their economic activities by planting more foodcrops. They also take greater care of the crops they use for canopy, such as oranges and kolanuts. The kolanut trade, which has been in existence since the inception of the cocoa trade, has grown in importance. Female traders, known as "alajapa" buy the kolanut. They start buying in January and stop in April. The alajapas buy the kolanut with the integument, and then sell them to retailers, who remove the cover from the kolanuts and sell these to Hausa traders, who ship the kolanuts to the great markets of the North (Group Interview 1990a, 1990b, $1990 \mathrm{c}, 1990 \mathrm{~d}) .^{17}$

The economic rewards of diversification have been encouraging. For example, an informant at Akeredolu said that, apart from the fact that he realized about 1,200 naira from kolanut sales in 1989 and 1990, he has also been making fairly decent profits from his fifteen-acre foodcrop farm. He realized about 4,300 naira in 1987, about 4,000 naira in 1988, and about the same amount in 1989. The cost of producing foodcrops also is significantly lower than the cost of producing cocoa (Adereti 1990). ${ }^{18}$ Cocoa farmers admit that, although cassava, maize, bananas, oranges, and other foodcrops will not replace cocoa farming, they have something to fall back on if cocoa is going through lean times. They cited the example of the price crash of 1988 and 1989, and suggested that, if it were not for the increased diversification of the cocoa industry, then many farmers would have abandoned their cocoa farms. Although foodcrop production is increasing owing to its short-term gains, most farmers are using the surplus generated from the sale of foodcrops to rehabilitate their cocoa farms. Most farmers at Ake- 
redolu realized between 1,000 and 4,000 naira from their foodcrop farms. Apart from the pecuniary benefits of these farms, they also met the foodstuff needs of the farmers.

\section{Conclusion}

The structural adjustment program was a response to two main problems. The glut in the world oil market depressed the price of oil from the unprecedented levels of the 1970s and early 1980s, and Nigeria's foreign exchange earnings fell. In order to meet up with an unwieldy recurrent expenditure and to pay for capital projects that were contracted during the oil boom, Nigeria depleted its foreign reserves. Nigeria then resorted to borrowing money from the IMF and the World Bank. By 1985, Nigeria's foreign debt had risen to about 21.2 billion naira. To compound this problem, Nigeria's economy grew at glacial speed. In order to be eligible for more loans from the major international financiers, Nigeria had to adjust its economy.

Structural Adjustment led to the devaluation of the naira, the deregulation of the economy, and a significant upsurge in inflation. This program had profound consequences for the cocoa trade. With the removal of government controls, market forces now determined the prices of cocoa beans and farm inputs. This generated a price war that led to a temporary boom in the cocoa trade. This boom, however, was artificial and did not reflect the actual market value of cocoa.

The severe inflationary situation of the Nigerian economy resulted in the increase in price of agricultural inputs such as fertilizers, chemicals, and farm implements. In addition, laborers increased their wages. Although in the short run some farmers were able to cope with these increases because of the substantial amounts they made during the boom, some of them began to find it difficult to maintain their farms after their gains had petered out.

Production increased substantially during the cocoa boom, and some farmers were able to rehabilitate their farms. The inability of farmers, however, to get adequate inputs on a sustained basis to maintain their farms has set in motion a spiral of decline. On the other hand, several hired laborers benefited immensely from the structural adjustment program as the farmers have had to hire them as sharecroppers, which fact has allowed them to save enough money to buy their own farms.

\section{ACKNOWLEDGEMENTS}

I would like to place on record my gratitude to the Rockefeller Foundation for funding this study. I would also like to recognize the very useful comments of John Hanson and two anon- 
ymous referees. Thanks are especially due to the farmers and laborers of Akeredolu, Mofere, Legbira, Fagbo, Igbo Oja, and Omifon Aladura, whose hospitality made fieldwork a truly rewarding experience.

\section{NOTES}

1 The naira is Nigeria's currency.

2 See Adedewe 1989, and Group Interview 1989a, 1989b, 1989c, 1989d, 1989e.

3 For information on Decree No. 18 of 1986, see Akanji 1992.

4 The cocoa main crop is usually harvested during the peak period of harvest, between November and March, and is usually heavier than the light crop, which is harvested from May through August.

5 See Group Interview 1989a, 1989b, 1989c, 1989d, 1990b, 1990c, 1990d, 1990e.

6 The author saw several cases of farmers organizing lavish parties while conducting fieldwork for this study between 1988 and 1991.

7 Annual Reports of the Association of Nigerian Cocoa Exporters 1988, 1989. Also see Fagboyegun 1990, and Opeke 1990.

8 For the sources used in Table 1, please see Akanji 1992:25, and Fadahunsi 1993: 37.

9 Several articles were written in various Nigerian newspapers during the cocoa boom between 1987 and 1988 that suggest that the high cocoa prices of the period were one of the positive benefits of the structural adjustment program. Fadahunsi and this author contend that the cocoa boom was artificially created and did not reflect the actual conditions of the Nigerian economy.

10 See for instance Akanji and Dorosh 1988.

11 See Group Interview 1989e, and Adereti 1989, 1990.

12 For the source used in Table 2, please see Akanji 1992: 9.

13 While doing fieldwork in the cocoa belt of Southwestern Nigeria the author visited several cocoa farms that had been decimated by cocoa diseases.

14 See Olufowomade 1989.

15 For the sources used in Table 3, please see Group Interview 1990a, 1991b, 1991 c.

16 See Group Interview 1990f, 1991a, 1991 b.

17 See Group Interview 1989a; 1990b.

18 See Adereti 1990.

\section{REFERENCES CITED}

Adedewe, Chief. 1989. Interview by author. Akeredolu, Osun State, Nigeria. 22-26 March. Adereti, Yaya. 1989. Interview by author. Akeredolu, Osun State, Nigeria. 22-26 March. -1990. Interview by author. Akeredolu, Osun State, Nigeria. 26-28 August.

Ahmad, Khan. 1994. The Political Economy of Oil-Exporting Countries. Oxford, England: University Press. 
Akanji, Bola. 1992. Cocoa Marketing under Nigeria's Structural Adjustment Programme. Ibadan, Nigeria: NISER.

Akanji, Bola, and Paul Dorosh. 1988. Impacts of Exchange Rate Changes on the Cocoa-Food Crop Farming Systems of Southwest Nigeria. Ibadan, Nigeria: International Institute of Tropical Agriculture.

Association of Nigerian Cocoa Exporters Annual Reports. 1988. Ibadan, Nigeria: Cooperative Press. 1989. Ibadan, Nigeria: Cooperative Press.

Colman, David, and Aja Okorie. 1998. The Effect of Structural Adjustment on the Nigerian Agricultural Export Sector. Journal of International Development 10(3): 341-55.

Daily Sketch. 1989. Editorial. 10 December.

Ekpo, Akpan. 1992. Employment and Inflation under Structural Adjustment: The Nigerian Experience. Eastern Africa Economic Review 8(2): 102-13.

Ekwe-Ekwe, Herbert. 1991. Issues in Nigerian Politics since the Fall of the Second Republic, 1984-1990. New York: Mellen Press.

Fadahunsi, Akin. 1993. Devaluation: Implications for Employment, Inflation, Growth and Development. In The Politics of Structural Adjustment, edited by Adebayo Olukoshi. London, England: James Curry.

Fagboyegun, Segun. 1990. Interview by author. 17 June. Owo, Ondo State, Nigeria.

Group Interview. 1989a. Interview by author. 10-13 March. Igbo Oja village, Ondo State, Nigeria.

- 1989 b. Interview by author. 15-18 March. Omifon Aladura, Ondo State, Nigeria.

- 1989c. Interview by author. 22-26 March. Akeredolu, Osun State, Nigeria.

- 1989d. Interview by author. 27 March. Fagbo, Ondo State, Nigeria.

- 1989e. Interview by author. 17-21 September. Molodo, Osun State, Nigeria.

.1990a. Interview by author. 15-17 April. Molodo, Osun State, Nigeria.

. 1990b. Interview by author. 15-19 August. Igbo Oja, Ondo State, Nigeria.

-1990c. Interview by author. 21-24 August. Omifon Aladura, Ondo State, Nigeria.

1990d. Interview by author. 26-28 August. Akeredolu, Osun State, Nigeria.

- 1990e. Interview by author. 30 August. Fagbo, Ondo State, Nigeria.

1990f. Interview by author. 7-11 December. Akeredolu, Osun State, Nigeria.

1991a. Interview by author. 18-21 February. Mofere, Ondo State, Nigeria.

1991b. Interview by author. 18-21 February. Legbira, Ondo State, Nigeria.

Husain, Ishrat, and Rashid Faruqee, eds. 1994. Adjustment in Africa: Lessons from Country Case Studies. Washington, D.C.:World Bank.

Ihonvbere, Julius. 1994. The Politics of Adjustment and Democracy. New Brunswick, New Jersey:Transaction Publishers.

Ola, Kayode. 1989. A Case for Indigenous Merchants. Sunday Sketch, 24 September.

Olatoye, Goke. 1988. Aliens Hijack Cocoa Trade. Sunday Sketch, 18 December.

Olufowomade, Aderibigbe. 1989. Interview by author. 10-13 March. Igbo-Oja, Ondo State, Nigeria.

Olukoshi, Adebayo O., ed. 1993 The Politics of Structural Adjustment in Nigeria. London, England: James Curry.

Opeke, Olu. 1990. Interview by author. 22 June. Ile Oluji, Ondo State, Nigeria.

Sunday Concord. 1989.6 August.

Sunday Tribune. 1989. Editorial, 26 November.

Yahaya, Shehu. 1993. The Privatisation Programme of the Nigerian State. In The Politics of Structural Adjustment, edited by Adebayo Olukoshi. London, England: James Curry. 